\title{
Antifungal activity of Lactobacillus gasseri and raisin extract against the growth of Aspergillus parasiticus in yogurt
}

\author{
Amal Bakr Shori*, Nouf Ahmed Batook and Samar Abdullah Alenisan \\ Department of Biological Sciences, Faculty of Science, King Abdulaziz University, Jeddah, Saudi Arabia
}

\begin{abstract}
Background and objective: Aspergillus parasiticus is a common fungus that produces aflatoxins and causes food contamination. Antifungal activity of Lactobacillus gasseri and raisins extract on the growth of Aspergillus parasiticus in yogurt (in vitro) were investigated.

Methodology: Two groups of yogurt samples were prepared. The first group consists of the plain yogurt with $L$. gasseri+A. parasiticus (control), and raisins yogurt with $L$. gasseri $+A$. parasiticus, and the second group consist of plain yogurt $+A$. parasiticus (control), and raisins yogurt $+A$. parasiticus. All yogurt samples were investigated for $\mathrm{pH}$, titratable acidity (TA), viable cells count of L. gasseri and inhibition of $A$. parasiticus growth during $1,7, \& 14$ days.

Results: The $\mathrm{pH}$ values of all samples were decreased non-significantly $(\mathrm{p}>0.05)$ during the storage period. The presence of raisins decreased ( $<<0.05)$ the total acidity in yogurt with L. gasseri $+A$. parasiticus $(1.53 \%)$ compared to control (1.98\%) at day 14 of storage. The viable cell numbers of $L$. gasseri $\left(0.27 \times 10^{6}\right.$ cfu/ml) in raisins yogurt $+A$. parasiticus was lower $(\mathrm{p}<0.05)$ than control $\left(0.39 \times 10^{6} \mathrm{cfu} / \mathrm{ml}\right)$ at day 14 of storage. Plain and raisins yogurt with $L$. gasseri showed moderate inhibition of A. parasiticus compared to without L. gasseri at 1 and 14 days of storage.
\end{abstract}

Conclusion: L. gasseri in a combination with raisins extract may have contributed to preventing $A$. parasiticus contamination in yogurt.

\section{Introduction}

Fermented milk products such as yogurt are possessed several nutritional values to the human diet [1]. This has long been recognized as a healthy food since ancient times and it continues to play even more essential role nowadays in the maintenance of health and as an important functional food in preventive medicine [2]. The nutritional value of yogurt is made up of milk's nutrients and the byproducts of probiotic fermentation of milk [3]. It is believed that these nutrients are capable to confer a variety of important nutritional and therapeutic benefits to consumers.

The growth of lactic acid bacteria (LAB) in milk resulted in several important changes in the milk components which include the reduction in lactose concentration, milk components degradation associated with lipolysis and proteolysis, and produce various antimicrobial agents [4]. Among the fermented milk products, yogurt exhibited effective barrier to the growth of many pathogens due to milk pasteurization and high acidity [5]. Consequently, controlling of the pathogen in dairy products has been established by using bacteriocins or bacteriocin-producing LAB as biological control [6].

Probiotics are known as "friendly bacteria' because they bring benefit to the human being by the metabolism that they conduct [7]. Probiotics such as Lactobacillus gasseri are viable organisms and supportive substances that improve intestinal microbial balance which is widely used in dairy products [8].

Mycotoxin-producing fungi are responsible for many foodborne diseases that arise naturally in the food [9]. However, certain probiotic strains can bind and remove mycotoxins from liquid media [10]. Aspergillus parasiticus is a fungus produces aflatoxins that cause food contamination as an opportunistic and pathogen [11].
Raisins (Vitis vinifera L.) are dried grapes that contain many properties including antimicrobial and antioxidant activity that related to a high concentration of phenolic compounds [12].

Probiotics are safe and widely used to increase immune response and prevent diseases. It is possible to use probiotics as an alternative to synthetic additives for preventing food from spoilage, as well as increasing nutritional value and therapeutic properties of food. Therefore, this study aims to investigate in vitro the effect of $L$. gasseri and raisins extract on the growth inhibition of $A$. parasiticus in yogurt during two weeks of refrigerated storage.

\section{Materials and methods}

\section{Materials}

Lactobacillus gasseri (EMCC 1930) and A. parasiticus (EMCC 886) was obtained from Egypt Microbial Culture Collection (EMCC), Cairo, Egypt. The bacterial culture was refreshed in de Mann Rogosa Sharpe (MRS) broth and incubated at $32^{\circ} \mathrm{C}$ for $24 \mathrm{~h}$ before streaked onto MRS agar and re-incubated at $32^{\circ} \mathrm{C}$ for $48 \mathrm{~h}$. A. parasiticus (EMCC 886) was refurbished via inoculation into potato dextrose broth (PDB) and incubated at $25^{\circ} \mathrm{C}$ for 3 days. Then, it was cultured on potato dextrose agar (PDA) plates and incubated at $28^{\circ} \mathrm{C}$ for 7 days. All media used were purchased from MICROMASTER, Maharashtra, India.

${ }^{\star}$ Correspondence to: Amal Bakr Shori, Department of Biological Sciences, Faculty of Science, King Abdulaziz University, Jeddah, Saudi Arabia, E-mail: shori_7506@hotmail.com

Key words: yogurt, Lactobacillus gasseri, Aspergillus parasiticus, raisins, antifungal, viability

Received: June 28, 2018; Accepted: July 17, 2018; Published: July 20, 2018 


\section{Water extraction of raisins}

Raisins were purchased from a local shop and prepared according to Mnari et al. [13] with some modification. Raisins $10 \mathrm{~g}$ were soaked in $90 \mathrm{ml}$ of distilled $\mathrm{H}_{2} \mathrm{O}$ for $24 \mathrm{~h}$ at room temperature. The mixture was thoroughly homogenized by using juice mixer. Then, the mixture was filtered and placed in a sterile plastic container. Raisins extract was kept in $-20^{\circ} \mathrm{C}$ fridge until required.

\section{Preparation of yogurt}

Yogurt was prepared according to shori and Baba [14] with some modification. Two groups of yogurt were prepared. The first group was prepared as following: pasteurized full cream milk $(85 \mathrm{ml})$ was mixed with $10 \mathrm{ml}$ of raisins water extract before added $4 \mathrm{~g}$ of full cream milk powder to regulate the milk solid content. Yogurt starter culture $(5 \mathrm{ml})$ containing Lactobacillus delbrueckii subsp. Bulgaricus, Streptococcus thermophilus and L. gasseri in the ratio of 1:1:4 was added and the milk mixture was mixed thoroughly and incubated in a water bath at $42^{\circ} \mathrm{C}$. Once the $\mathrm{pH}$ was reached 4.5 the yogurt was taken out and cooled down. Spore suspensions of $A$. parasiticus ( $1 \mathrm{ml}$ ) containing a spore number of $\sim 10^{5}$ spores $/ \mathrm{ml}$ were inoculated to the yogurt before stored in the refrigerator $\left(4^{\circ} \mathrm{C}\right)$. Plain yogurt was prepared in the similar method except replacing raisins water extract with distilled water $\left(\mathrm{dH}_{2} \mathrm{O}\right)$. The second group was prepared in the same method as the first group but yogurt starter culture containing no L. gasseri. Four yogurt samples (plain yogurt with $L$. gasseri+A. parasiticus (control), raisins yogurt with $L$. gasseri + A. parasiticus, plain yogurt + A. parasiticus (control), and raisins yogurt $+A$. parasiticus) were analyzed for $\mathrm{pH}$, titratable acidity, viable cells counts of $L$. gasseri and inhibition of $A$. parasiticus growth during $1,7, \& 14$ days.

\section{The $\mathrm{pH}$ measurement and titratable acid (TA \%)}

The changes in $\mathrm{pH}$ during the storage of yogurt were measured every 1,7 and 14 days [15]. A known volume $(1 \mathrm{ml})$ of yogurt was

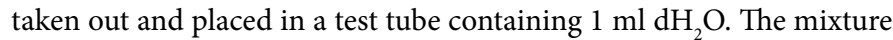
was homogenized and the $\mathrm{pH}$ was measured using a digital $\mathrm{pH}$ meter (Mettler-Toledo 320). The titratable acid (TA) was determined by titration using $\mathrm{NaOH}$. Samples of yogurt $(1 \mathrm{ml})$ taken at the same time for $\mathrm{pH}$ determination and placed in Erlenmeyer flask containing $9 \mathrm{ml}$ $\mathrm{dH}_{2} \mathrm{O}$ followed by the addition of three drops of $0.1 \%$ phenolphthalein which was prepared by dissolving $1 \mathrm{~g}$ of phenolphthalein in $100 \mathrm{ml}$ of ethanol. $\mathrm{NaOH}(0.1 \mathrm{~N})$ was titrated into the solution and the mixture was properly mixed by swirling the flask. The titration was continued until the color of the solution changed to slightly pink which was stable for at least 15-20 seconds. The amount of acid produced during fermentation was calculated as follows:

\section{$\mathrm{TA} \%=$ Dilution factor $(10) \times \mathrm{V} \mathrm{NaOH} \times 0.1 \mathrm{~N} \times 0.009 \times 100 \%$}

where $\mathrm{V}$ is the volume of $\mathrm{NaOH}$ required to neutralize the acid and 0.009 represent the weight of lactic acid (g) neutralized by $1 \mathrm{ml} 0.1 \mathrm{~N}$ $\mathrm{NaOH}$.

\section{Buffered peptone water}

Buffered peptone water $(20 \mathrm{~g})$ was mixed with $1 \mathrm{~L}$ distilled water, the mixture place in a tightly closed flask followed by autoclaved (Panasonic, MLS- 3781-PK) at $121^{\circ} \mathrm{C}$ for $15 \mathrm{~min}$ [14]. Yogurt samples were initially diluted serially to the desired dilution factor using sterilized buffered peptone water and the dilutions were done to $10^{3}$.

\section{Enumeration of L. gasseri using the spread count method}

Diluted yogurt sample $(1 \mathrm{ml})$ was transferred to the MRS agar plate, the mixture was evenly mixed by lope [16]. Parafilm was used for sealing the petri dishes to prevent entry of air. Thereafter, the plates were inverted and located in the incubator $\left(37^{\circ} \mathrm{C}\right)$ for $48 \mathrm{~h}$. The viable cell count was calculated as follows:

$\mathrm{CFU}^{*} / \mathrm{ml}=($ Number of colonies formed $\times$ dilution of sample $) / 1 \mathrm{ml}$ of sample

$* \mathrm{CFU}$ : colony forming unit

\section{Determination the growth rate of $A$. parasiticus}

The growth of $A$. parasiticus was determined as described by Chukwuemeka and Ibe [17]. PDA agar was prepared by mixing $39 \mathrm{~g}$ of PDA powder in $1000 \mathrm{ml}$ distilled water and the solution was autoclaved at $121^{\circ} \mathrm{C}$ for $15 \mathrm{~min}$. Sterilized PDA media was transferred into petri dishes and the agar was allowed to solidify for 10 minutes. $1 \mathrm{ml}$ of diluted yogurt was transferred onto PDA agar surface and was spread by the lope. The plates were placed in the incubator $\left(28^{\circ} \mathrm{C}\right)$ for 7 days. The growth of $A$. parasiticus was recorded as follow:

$(-)=$ no growth; $(+)=$ low growth; $(++)=$ medium growth; $(+++)$ $=$ heavy growth.

\section{Statistical analysis}

The experiments were carried out in three different batches of yogurt $(n=3)$ and all assays were performed in duplicate. The results were expressed as mean \pm S.E.M (standard mean error). Data were analyzed using one-way analysis of variance (ANOVA, SPSS 19.0), followed by Duncan's post hoc test for mean comparison. The criterion for statistical significance was $\mathrm{p}<0.05$.

\section{Results}

\section{Post-acidification of yogurt}

The changes in the $\mathrm{pH}$ and TA of yogurt samples were shown in Figures 1 and 2. There were no significant differences $(\mathrm{p}>0.05)$ in $\mathrm{pH}$ between the two groups of treatment both in the presence and absence of L. gasseri (Figure 1). The $\mathrm{pH}$ of all treated samples ranged from 4.5 4.2 during two weeks of storage. The total acidity in the two groups of treatment was not significant ( $p>0.05)$ compared to their respective controls (Figure 2). However, the presence of raisins decreased $(\mathrm{p}<0.05)$ the total acidity in yogurt with $L$. gasseri+A. parasiticus $(1.53 \%)$ compared to plain yogurt with L. gasseri+A. parasiticus $(1.98 \%)$ at day 14 of storage. Prolonged refrigerated storage to 14 days increased significantly $(\mathrm{p}<0.05)$ the total acidity of yogurt in all treated samples.

\section{Viability of L. gasseri in yogurt}

The viability of $L$. gasseri showed almost similar values $(\mathrm{p}>0.05)$ in both control and treated yogurt at day 1 and 7 of refrigerated storage (Figure 3). However, the presence of raisins had negative effects on the viable cell numbers of $L$. gasseri $\left(0.27 \times 10^{6} \mathrm{cfu} / \mathrm{ml}\right)$ in yogurt compared to control $\left(0.39 \times 10^{6} \mathrm{cfu} / \mathrm{ml}\right)$ at day 14 of storage.

Effects of raisins and L. gasseri on the growth rate of $A$. parasiticus in yogurt

The growth rate of $A$. parasiticus in yogurt samples both in the presence and absence of raisins extracts and L. gasseri was shown in Table 1. The present result showed that inclusion of raisins extracts in yogurt with L. gasseri had no effects on inhibition of $A$. parasiticus 
growth compared to control. However, raisins yogurt showed higher inhibition of growth of $A$. parasiticus (+) than plain yogurt $(+++)$ at day 14 of storage. In addition, prolonged refrigerated storage showed a positive effect on $A$. parasiticus growth inhibition in raisins yogurt (Table 1). Plain and raisins yogurt with $L$. gasseri showed moderate inhibition of A. parasiticus compared to without L. gasseri at 1 and 14 days of storage.

\section{Discussion}

One of the distinguishing features of using probiotics in food is that having an antimicrobial activity against disease-causing

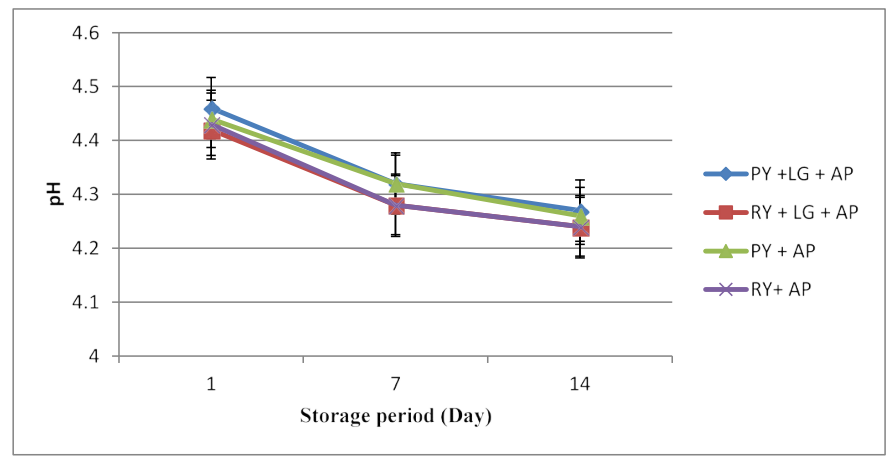

Figure 1. Changes in $\mathrm{pH}$ value of yogurt samples during 14 days of refrigerated storage $\left(4^{\circ} \mathrm{C}\right)$

"AP=Aspergillus parasiticus, $\mathrm{LG}=$ Lactobacillus gasseri, $\mathrm{RY}=\mathrm{Raisin}$ yogurt, $\mathrm{PY}=\mathrm{Plain}$ yogurt

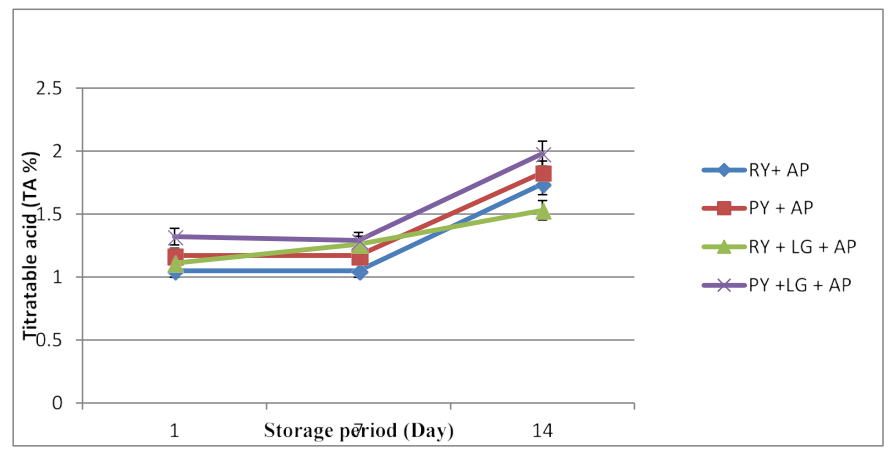

Figure 2. Changes in titratable acid (TA \%) of yogurt samples during 14 days of refrigerated storage $\left(4^{\circ} \mathrm{C}\right)$

"AP $=$ Aspergillus parasiticus, $\mathrm{LG}=$ Lactobacillus gasseri, $\mathrm{RY}=\mathrm{Raisin}$ yogurt, $\mathrm{PY}=\mathrm{Plain}$ yogurt

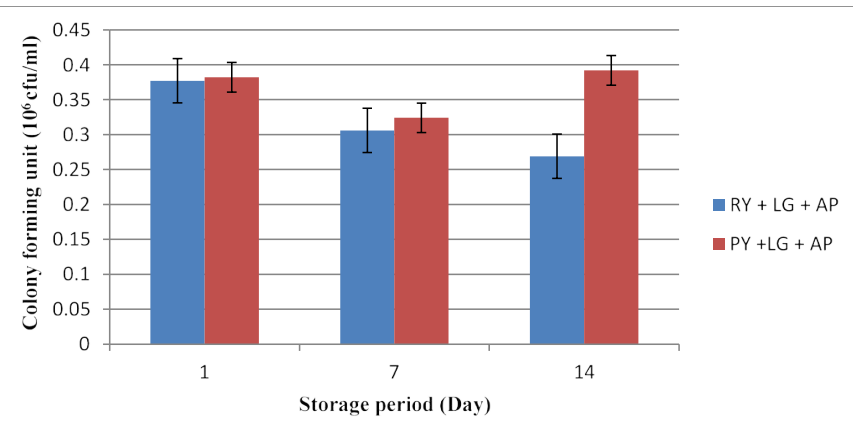

Figure 3. The viable cell counts of L. gasseri in yogurt during 14 days of refrigerated storage $\left(4^{\circ} \mathrm{C}\right)$

*AP=Aspergillus parasiticus, $\mathrm{LG}=$ Lactobacillus gasseri, $\mathrm{RY}=$ Raisin yogurt, $\mathrm{PY}=\mathrm{Plain}$ yogurt
Table 1. The growth rate of $A$. parasiticus in yogurt samples during 14 days of refrigerated storage $\left(4^{\circ} \mathrm{C}\right)$

\begin{tabular}{|c|c|c|c|c|}
\hline Storage day & $\mathbf{P Y}+\mathbf{A P}$ & $\mathbf{R Y}+\mathbf{A P}$ & $\mathbf{P Y + L G + A P}$ & $\mathbf{R Y + L G + A P}$ \\
\hline $\mathbf{1}$ & +++ & +++ & ++ & ++ \\
\hline $\mathbf{7}$ & ++ & ++ & ++ & ++ \\
\hline $\mathbf{1 4}$ & +++ & + & ++ & ++ \\
\hline
\end{tabular}

"AP=Aspergillus parasiticus, $\mathrm{LG}=$ Lactobacillus gasseri, $\mathrm{RY}=$ Raisin yogurt, $\mathrm{PY}=\mathrm{Plain}$ yogurt

organisms. This is related to a strong antagonistic activity against foodcontaminated microbes by the production of organic acids, enzymes, and other substances $[18,19]$. Most fungi are sensitive to normal secondary products produced by lactic acid bacteria metabolites [20]. LAB are generally found in various fermented foods such as dairy products, cereals, beverages, fruit and vegetable juices [21]. It has been traditionally applied in food as bio-preservatives which attribute to prolonged shelf-life and advanced the safety of foods [22].

In this study, the decline of $\mathrm{pH}$ in yogurt during refrigerated storage contributed to the accumulation of organic acid i.e. lactic acid produced by yogurt starter culture as metabolic byproducts [23]. The presence of raisins affected negatively the total acidity in yogurt with $L$. gasseri $+A$. parasiticus compared to control at day 14 of storage. This could be associated with the low viability of L. gasseri in yogurt (Figure 3 ).

Raisins have high concentrations of naturally occurring phenolic compounds with effective antimicrobial and antioxidant activities [12]. In contrast, the present study showed no effects of raisins on the viability of $L$. gasseri as probiotics. This is in disagreement with previous studies that showed the addition of medicinal plants affected significantly the growth of probiotics in yogurt and other dairy products [7,14,24-27]. The addition of raisins in yogurt inhibited the growth of $A$. parasiticus at $7 \& 14$ days which may occur as a result of raisins phenolic compounds with antimicrobial activity [28]. Further studies are needed to evaluate and characterize the phenolic profiles of raisins yogurt with antimicrobial activity. The moderate effects of plain and raisins yogurt with L. gasseri on inhibition of A. parasiticus may refer to some physical factors that affect antimicrobial activity of raisins such as low $\mathrm{pH}$, low water activity, and high osmolality [12]. Gamba et al. [28] have observed that kefir-cell-free-supernatants produced antifungal activity against $A$. parasiticus at $\mathrm{pH} 3.5$ and concentration of $65 \%$ v/v. Furthermore, probiotic bacteria such as Lactobacillus delbrueckii and Lactobacillus rhamnosus showed significant effect on the growth inhibition of $A$. parasiticus, morphological structure, and reducing aflatoxin production [30].

\section{Conclusion}

Raisins had no effect on post-acidification and the viability of $L$. gasseri in yogurt. In addition, L. gasseri showed antagonistic activity against $A$. parasiticus. Therefore, L. gasseri in a combination with raisins extract may have contributed to preventing $A$. parasiticus contamination in yogurt. This mechanism can be applied for preventing yogurt spoilage by $A$. parasiticus during storage. Moreover, further study is needed to understand the mechanism of antifungal activity by L. gasseri and raisins extract in yogurt and the possibility of using it as bio-preservatives.

\section{Acknowledgment}

The authors acknowledge Science Research and Innovation Unit of Science Faculty at King Abdulaziz University (KAU), Jeddah, Saudi Arabia and KAU Research Endowment Fund for their financial support. 


\section{References}

1. Shori AB, Rashid F, Baba AS (2018) Effect of the addition of phytomix-3+ mangosteen on antioxidant activity, viability of lactic acid bacteria, type 2 diabetes key-enzymes, and sensory evaluation of yogurt. LWT - Food Sci Technol 94: 33-39.

2. Muniandy P, Shori AB, Baba AS (2016) Influence of green, white and black tea addition on the antioxidant activity of probiotic yogurt during refrigerated storage. Food Pack Shelf Life 8: 1-2

3. Shori AB, Baba AS (2011) Cinnamomum verum improved the functional properties of bio-yogurts made from camel and cow milks. J Saudi Soc Agri Sci 10: 101-107.

4. Deguchi R, Nakaminami H, Rimbara E, Noguchi N, Sasatsu M, et al. (2012) Effect of pretreatment with Lactobacillus gasseri OLL2716 on first-line Helicobacter pylori eradication therapy. J Gastroenterol Hepatol 27: 888-892. [Crossref]

5. Benkerroum N, Oubel H, Sandine WE (2003) Effect of nisin on yogurt starter, and on growth and survival of Listeria monocytogenes during fermentation and storage of yogurt. Int J Food Saf 1: 1-5.

6. Benkerroum N, Oubel H, Zahar M, Dlia S, Filali-Maltouf A (2000) Isolation of a bacteriocinproducing Lactococcus lactis subsp. lactis and application to control Listeria monocytogenes in Moroccan Jben. J Appl Microbiol 89: 960- 969. [Crossref]

7. Shori $A B(2016)$ Influence of food matrix on the viability of probiotic bacteria: an overview based on dairy and non-dairy beverages. Food Biosci 13: 1-8.

8. Fujiwara S, Seto Y, Kimura A, Hashiba H (2001) Establishment of orally-administered Lactobacillus gasseri SBT2055SR in the gastrointestinal tract of humans and its influence on intestinal microflora and metabolism. J Appl Microbiol 90: 343-52. [Crossref]

9. Sani AM, Marhamati Z, Marhamatizade MH (2014) Bio-detoxification of aflatoxin M1 in kefir using Lactobacillus casei. Biotechnol Indian J 9: 221-224.

10. Vinderola G, Ritieni A (2014) Role of probiotics against mycotoxins and their deleterious effects. J Food Res 4: 10.

11. Perrone G, Susca A, Cozzi G, Ehrlich K, Varga J, et al. (2007) Biodiversity of Aspergillus species in some important agricultural products. Stud Mycol 59: 53-66. [Crossref]

12. Bower CK, Schilke KF, Daeschel MA (2003) Antimicrobial properties of raisins in beef jerky preservation. J Food Sci 68: 1484-1489.

13. Mnari AB, Amri AHZ, Aguir SD, Hammami M (2015) Phytochemical Content, Antioxidant Properties, and Phenolic Profile of Tunisian Raisin Varieties (Vitis Vinifera L.). Int J Food Prop 19: 578-590.

14. Shori AB, Baba AS (2012) Viability of lactic acid bacteria and sensory evaluation in Cinnamomum verum and Allium sativum-bio-yogurts made from camel and cow milk. $J$ Assoc Arab Univer Basic Appl Sci 11: 50-55.

15. Shori AB, Baba AS (2013) Antioxidant activity and inhibition of key enzymes linked to type-2diabetes and hypertension by Azadirachta indica-yogurt. J Saudi Cheml Soc 17: $295-301$.
16. Shori AB (2013) Antioxidant activity and viability of lactic acid bacteria in soybeanyogurt made from cow and camel milk. J Taibah Univ Sci 7: 202-208.

17. Chukwuemeka ON, Ibe S N (2013) Effect of storage temperature on shelf-life of yogurt-like product from soybean (Glycine max). Scientia Africana 12.

18. Kachouri F, Ksontini H, Hamdi M (2014) Removal of aflatoxin B1 and inhibition of Aspergillus flavus growth by the use of Lactobacillus plantarum on olives. $J$ Food Prot 77: 1760-1767. [Crossref]

19. Sevgi E, Tsveteslava II (2015) Antifungal Activity of Lactic Acid Bacteria, Isolated from Bulgarian Wheat and Rye Flour. J Life Sci 9: 1-6.

20. Oranusi SU, Braide W, Oguoma OI (2013) Antifungal properties of lactic acid bacteria (LAB) isolated from Ricinus communis, Pentaclethra macrophylla and Yoghurts. Glob Adv Res J Food Sci Technol 2: 1-6.

21. Shori AB, Baba AS (2014) Comparative antioxidant activity, proteolysis and in vitro $\alpha$-amylase and $\alpha$-glucosidase inhibition of Allium sativum-yogurts made from cow and camel milk. J Saudi Chem Soc 18: 456-463.

22. Schnürer J, Magnusson J (2005) Antifungal Lactic Acid Bacteria as Bio Preservatives. Trends Food Sci Technol 16: 70-78.

23. Shori AB (2013) Nutritional and therapeutical values of chickpea water extract enriched yogurt made from cow and camel milk. Am J Drug Discov Develop 3: 47-59.

24. Shori AB, Baba AS (2014) Survival of Bifidobacterium bifidum in cow- and camelmilk yogurts fortified with Cinnamomum verum and Allium sativum. Journal of the $J$ Assoc Arab Univ Basic Appl Sci 18: 7-11.

25. Baba AS, Najarian A, Shori AB, Lit KW, Keng GA (2014) In vitro inhibition of key enzymes related to diabetes and hypertension in Lycium barbarum-yogurt. Arab J Sci Eng 39: 5355-5362.

26. Shori AB (2015) The potential applications of probiotics on dairy and non-dairy foods focusing on viability during. Biocata Agri Biotechnol 4: 423-431.

27. Muniandy P, Shori AB, Baba AS (2017) Comparison of the effect of green, white and black tea on Streptococcus thermophilus and Lactobacillus spp. in yogurt during refrigerated storage. J Assoc Arab Univer Basic Appl Sci 22: 26-30.

28. Rivero-Cruz JF, Zhu M, Kinghorn AD, Wu CD (2008) Antimicrobial constituents of Thompson seedless raisins (Vitis vinifera) against selected oral pathogens. Phytochem Lett 1: 151-154.

29. Gamba RR, Colo CN, Correa M, Astoreca A, Alconada T, et al. (2015) Antifungal Activity against Aspergillus parasiticus of Supernatants from Whey Permeates Fermented with Kefir Grains. Adv Microbiol 5: 479-492.

30. Bokhari FM, Alenisan MA, Shori AB (2018) Effect of probiotic bacteria on the growth and mycotoxin production of two toxigenic fungi. Int J Curr Res 10: 6820968215 .

Copyright: (C2018 Shori AB. This is an open-access article distributed under the terms of the Creative Commons Attribution License, which permits unrestricted use, distribution, and reproduction in any medium, provided the original author and source are credited. 